\title{
Susceptibility of Egg Stage of Potato Tuber Moth Phthorimaea operculella to Native Isolates of Beauveria bassiana
}

\author{
Nisreen Houssain Alsaoud, \\ Doummar Hashim Nammour and Ali Yaseen Ali
}

Additional information is available at the end of the chapter

http://dx.doi.org/10.5772/intechopen.78391

\begin{abstract}
The pathogenicity of three local isolates of the entomopathogenic fungus Beauveria bassiana (Bals.) Vuill was evaluated on eggs of potato tuber moth P. operculella (Zeller). The three isolates were coded as the following: B (isolate from Latakia), C (isolate from ICARDA) and $\mathrm{D}$ (isolate from Damascus). Three concentrations $10^{4}, 10^{5}$, and $10^{6}$, respectively, conidia/ml were used for each isolate. Eggs in the control were sprayed by sterilized water. All tests were done under laboratory conditions of temperature $28 \pm 2^{\circ} \mathrm{C}$ and relative humidity $40 \pm 5 \%$. Susceptibility tests showed significant differences in averages of hatching rate between the control and both isolates $B$ and $C$ when $1 \times 10^{6}$ conidia/ml was applied, with averages 18.3 and $26.6 \%$ for previous isolates respectively, in contrast to 38.3 for isolate $\mathrm{D}$ and $66.6 \%$ for control. Findings indicated that eggs of $P$. operculella seemed sensible to local isolates of $B$. bassiana in varying degree, but further studies are required about the efficiency of effective isolates for controlling eggs of this pest in natural conditions.
\end{abstract}

Keywords: Beauveria bassiana, pathogencity, Phthorimaea operculella, Syrian isolates

\section{Introduction}

Potato tuber moth (Gelechiidae: Lepidoptera) Phthorimaea operculella is one of worldwide spread pests on potato and Solanaceae $[1,2]$. The female lay her eggs on the leaves and noncovered tubers near to eyes (buds), larvae dig tunnels during their nutrition causes damages that reach approximately $100 \%$ on cultivated and stored potato $[3,4]$. Therefore, this moth 
must be controlled in the field and in the store. There are many ways to control this pest starting by synthetic organic pesticides [5], natural origin insecticides like botanical extracts [6] and using genetically modified plants [5, 7, 8]. Natural parasitic enemies also successfully used like wasps from Braconidae, in addition to insect predators from Coccinellidae, Chrysopidae and Formicidae [9] and parasitic nematodes like Steinernema carpocapsae, S. feltiae, S. glaseri, and Heterorhabditis bacteriophora [10] which used successfully too. In last decade, biological origin insecticides like entomopathogenic viruses from group baculovirus [11] are used, as well as entomopathogenic fungi like Beauveria bassiana (Hypocreales: clavicipitaceae) $[12,13]$.

In this chapter, the pathogenicity of three native isolates of entomopathogenic fungus Beauveria bassiana was studied in different concentrations on eggs of potato tuber moth Phthorimaea operculella (Zeller), and it was determined the isolate which is the most pathogenicity on eggs, in vitro.

\section{Materials and methods}

\subsection{Insect rearing}

Tubers infected by potato tuber moth were collected from local markets, and laid on fine sand in aired glass cages $(30 \times 45 \mathrm{~cm})$. Insects grew inside the cages in large numbers and fed by sugar solution (90\%). Cages were supplied with fresh infected and noninfected tubers for activating insect rearing under laboratory conditions $28^{\circ}$ C, R.H. $40 \pm 5 \%$.

\subsection{Egg collecting}

Eggs that are 1-day age were collected by using egg collecting chamber, which were prepared in the same manners of Maharjan [14], the chamber consists of plastic jar $(7 \times 15 \mathrm{~cm})$ supplied with a cotton ball immersed in sugar solution. Five couples of moth adults (five males and five females) entered into the jar, and covered with gauze that was fixed by rubber, there is a piece of paper above the gauze. Eggs found on this paper were collected daily without opening the chamber [15]. Adults were fed by injecting the cotton ball (inside the jar) with sugar solution.

\subsection{Infecting material and the spore suspension preparation}

Three native isolates of the entomopathogenic fungus B. bassiana were used and were taken from different areas in Syria (Table 1).

Infecting material was prepared in safety bio-cabinet on Malt Extract Agar (MEA) medium in petri dishes of $9 \mathrm{~cm}$ in diameter, and dishes were placed inside a dark incubator at $25^{\circ} \mathrm{C}$. Spores were harvested from dishes 2 weeks later, by adding $5 \mathrm{ml}$ sterilized water for each dish then dish's contents were filtered across three layers of gauze. In addition, $5 \mathrm{ml}$ of sterilized water was added over the gauze to assure collecting the maximum number of spores. The result liquid, which is considered as base solution $0.05 \%$ of tween $80 \%$, was added to it. 


\begin{tabular}{llll}
\hline Isolate name & Isolate code & Source & Isolate site \\
\hline Latakia & $\mathrm{B}$ & Biological Enemies Center, Latakia & Soil of citrus orchard, Latakia \\
Icarda spt273 & $\mathrm{C}$ & ICARDA, Aleppo & $\begin{array}{l}\text { Isolated from dead Eurygaster integriceps, } \\
\text { Aleppo }\end{array}$ \\
Damascus & $\mathrm{D}$ & Biotechnology Center, Damascus & $\begin{array}{l}\text { Isolated from dead Eurygaster integriceps, } \\
\text { Damascus }\end{array}$ \\
\hline
\end{tabular}

Table 1. Native isolates of entomopathogenic fungi B. bassiana and their sources and isolation sites.

Base solution concentration was determined by using a slide named Neubauer improved. The concentrations were adjusted for the three isolates to be: $10^{4}, 10^{5}, 10^{6}$ conidia/ml. Control was treated with sterilized water and $0.05 \%$ of tween $80 \%$ was added to it.

\subsection{Germination test}

For testing the vitality of spores for each isolate, germination test was done in darkness under laboratory condition $28 \pm 2{ }^{\circ} \mathrm{C}$, R.H. $40 \pm 5 \%$ where $5 \mu \mathrm{l}$ from each isolate, at the concentration of $10^{4} \mathrm{spore} / \mathrm{ml}$, was distributed on three drops on small petri dish of $5 \mathrm{~cm}$ diameter that contained Agar-Agar medium. Every drop represents a replicate that was covered by a covering glass before it was closed and then the dish was placed in a dark chamber. Next day, germinated spores were counted from 100 spores under every covering glass; after it was colored by lactophenol Cotton Blue, and the average of germination ratio was calculated for every isolate from its own dish.

\subsection{Egg infecting by the fungus spore}

A total of 600 eggs of potato tuber moth, 1 day age, were distributed into 30 carton cups that equal to 20 eggs/cup. Nine cups for each isolate distributed into three cups for each studied concentration $\left(10^{4}, 10^{5}, 10^{6}\right.$ spore/ml), as well as three cups for control. Replicate eggs were sprayed with $2 \mathrm{ml}$ of every solution by "Perfume Water Spray Bottle." Eggs in control were sprayed with $2 \mathrm{ml}$ of sterilized water with $0.05 \%$ of tween $80 \%$ were added. After eggs spraying, inside their cups, they were covered with fine gauze which is fixed by rubber. Cups were placed in chamber at $28 \pm 2^{\circ} \mathrm{C}$, and R.H. $40 \pm 5 \%$.

\subsection{Readings}

Hatching of treated eggs was observed to record the number of neonates, for 6 days period, in all treatments including the control. Hatched eggs ratio and dead eggs ratio were calculated when hatching was over, and nonhatched eggs were examined under $10 \times$ to record their color changes.

\subsection{Data analysis}

Percentage of corrected mortality was calculated according to Abbott [16]. 
$\%$ Corrected mortality $=(\%$ mortality in control $-\%$ mortality in treatment $) \times 100 /$

(100\% mortality in control)

Data were analyzed by using SPSS program, where treatments were compared to test the significance of difference between averages by using LSD test at $p=0.05$.

\subsection{Scanning under electronic microscope}

Eggs treated with local isolates of $B$. bassiana were observed under scanning electron microscope (SEM) and described in Science Faculty, Albaath University, according to its characteristics.

\section{Results}

\subsection{Germination ratio}

Averages of germination, after $24 \mathrm{~h}$, were ranged between 47 and 67\% (Table 2). Isolate B realized that has more germination ratio $(67 \%)$ with significant difference from the isolate $\mathrm{C}$ which reached $48 \%$, while isolate $\mathrm{D}$ reached to $55 \%$. There is a significant difference in germination ratio between $\mathrm{B}$ and $\mathrm{C}$.

\subsection{Susceptibility of eggs}

Reduction in hatchability rate was remarked in all treatments in comparison with control. Control realized a ratio of hatchability $66.6 \%$, but this reduction in hatchability was not significant, between the control and the isolates, except in treatment with higher concentration $\left(10^{6} \mathrm{spore} / \mathrm{ml}\right)$ for the two isolates B and C (Table 3). Hatchability rate was $18.3 \%$ for isolate $\mathrm{B}$ and $26.6 \%$ for isolate $\mathrm{C}$. There was no significant difference in hatchability between the isolate $\mathrm{D}$ and other treatments for the same previous concentration. Hatchability rates for the concentration $10^{5} \mathrm{spore} / \mathrm{ml}$ were higher than $10^{6} \mathrm{spore} / \mathrm{ml}, 33.3,41.6$ and $36.6 \%$ for isolates B, $\mathrm{D}$ and $\mathrm{C}$, respectively.

\begin{tabular}{ll}
\hline Isolate name & Germination (average \pm SE) \\
\hline B & $67 \pm 5.77 \mathrm{a}$ \\
D & $55 \pm 5.57 \mathrm{ab}$ \\
C & $47 \pm 4.33 \mathrm{~b}$ \\
LSD & 14.46 \\
\hline
\end{tabular}

Means with same small letters in the same column have no significant differences at $p=0.05$.

Table 2. Means of germination rates of native isolates of $B$. bassiana fungus at temperature $28 \pm 2{ }^{\circ} \mathrm{C}$ and relative humidity $40 \pm 5 \%, 24 \mathrm{~h}$ after incubation. 


\begin{tabular}{llll}
\hline $\begin{array}{l}\text { Treatment-isolate/ } \\
\text { concentration }\end{array}$ & $\begin{array}{l}\text { Hatching rate of eggs } \\
\text { (average } \pm \text { SE) }\end{array}$ & $\begin{array}{l}\text { Mortality of eggs } \\
\text { (average } \pm \text { SE) }\end{array}$ & $\begin{array}{c}\text { Corrected } \\
\text { mortality }\end{array}$ \\
\hline Control & $66.6 \pm 14.5 \mathrm{a}$ & $33.3 \pm 14.5$ & - \\
Isolate B $10^{6}$ conidia/ml & $18.3 \pm 1.6 \mathrm{~b}$ & $81.6 \pm 1.6$ & 72.5 \\
Isolate D $10^{6}$ conidia/ml & $38.3 \pm 13 \mathrm{ab}$ & $61.6 \pm 13$ & 42.5 \\
Isolate C $10^{6}$ conidia/ml & $26.6 \pm 1.6 \mathrm{~b}$ & $73.3 \pm 1.6$ & 60 \\
LSD value & 25.84 & - & 50 \\
Isolate B $10^{5}$ conidia/ml & $33.3 \pm 10.9 \mathrm{a}$ & $66.6 \pm 10.9$ & 37.5 \\
Isolate D $10^{5}$ conidia/ml & $41.6 \pm 6.6 \mathrm{a}$ & $58.3 \pm 11.5$ & 45 \\
Isolate C $10^{5}$ conidia/ml & $36.6 \pm 6.6 \mathrm{a}$ & $63.3 \pm 6.6$ & - \\
LSD value & 26.94 & - & 47.5 \\
Isolate B $10^{4}$ conidia/ml & $35 \pm 17.5 \mathrm{a}$ & $65 \pm 17.5$ & 32.5 \\
Isolate D $10^{4}$ conidia/ml & $45 \pm 13.2 \mathrm{a}$ & $55 \pm 13.2$ & 35 \\
Isolate C $10^{4}$ conidia/ml & $43.3 \pm 12.01 \mathrm{a}$ & $56.6 \pm 6.16$ & - \\
LSD value & 38 & - & - \\
\hline
\end{tabular}

Means with same small letters in the same column have no significant differences at $p=0.05$.

Table 3. Means of hatching rates of $P$. operculella eggs after the treatment by different isolates of the entomopathogenic fungus $B$. bassiana with different concentrations at $28 \pm 2^{\circ} \mathrm{C}$ and relative humidity $40 \pm 5 \%$.

Isolates in the concentration of $10^{4}$ spore/ $\mathrm{ml}$ were realized with higher hatchability rates: 35 , 45,43 and $67 \%$ for B, D, C and control; respectively.

In concentration $10^{6} \mathrm{spore} / \mathrm{ml}$, the isolate B reached the top corrected mortality rate on egg followed by C then D: 72.5, 60, 42.5\%, respectively. These rates decreased to 50, 37.5 and $45 \%$ for the same previous isolates respectively, in concentration $10^{5} \mathrm{spore} / \mathrm{ml}$. In contrast, the lowest corrected mortality rates were in concentration $10^{4}$ spore $/ \mathrm{ml}: 47.5,32.5$ and $35 \%$ for B, D and C, respectively (Table 2).

\subsection{Observing non-hatched egg}

Number of dead eggs (nonhatched) resulted from the different treatments changed their color from transparent to yellowish or black. Black eggs percentage from dead eggs was 3, 7 and $20 \%$ for isolates D, C and B respectively in the concentration $10^{6} \mathrm{spore} / \mathrm{ml}$, as well as they were 8,8 and $20 \%$ for the same previous isolates in the concentration $10^{5} \mathrm{spore} / \mathrm{ml}$ and 5,9 and $12 \%$ for the same isolates in the concentration $10^{4}$ spore/ml (Table 4).

Eggs of potato tuber moth were shown under scanning electron microscopes (SEM) (Image 1), on the left, smooth egg's shell with some sculptures were shown under $400 \times$ as well as a slot of larva emergence at the pole of egg. On the right, infected egg by B. bassiana was seen under 800×, where spores have distributed on the surface especially in sculptures, but the density of spores was not so high where egg has hatched so it was shown a slot of larva emergence. 


\begin{tabular}{llll}
\hline $\begin{array}{l}\text { Treatment-isolate/ } \\
\text { concentration }\end{array}$ & $\begin{array}{l}\text { Transparent dead eggs } \% \\
\text { (average } \pm \text { SE) }\end{array}$ & $\begin{array}{l}\text { Yellow dead eggs } \% \\
\text { (average } \pm \text { SE) }\end{array}$ & $\begin{array}{l}\text { Black dead eggs } \\
\text { (average } \pm \text { SE) }\end{array}$ \\
\hline Control & $78 \pm 8.82$ & $19 \pm 6.66$ & $0 \pm 0$ \\
Isolate B $10^{6}$ conidia/ml & $80 \pm 12.58$ & $0 \pm 0$ & $20.3 \pm 12.02$ \\
Isolate D $10^{6}$ conidia/ml & $97 \pm 13.23$ & $0 \pm 0$ & $2.5 \pm 1.66$ \\
Isolate C $10^{6}$ conidia/ml & $84 \pm 1.66$ & $16 \pm 6$ & $6.8 \pm 2.88$ \\
Isolate B $10^{5}$ conidia/ml & $87 \pm 12$ & $5 \pm 3.33$ & $7.5 \pm 2.89$ \\
Isolate D $10^{5}$ conidia/ml & $71 \pm 4.4$ & $8.5 \pm 2.89$ & $19.9 \pm 4.4$ \\
Isolate C $10^{5}$ conidia/ml & $81 \pm 8.82$ & $10.4 \pm 1.66$ & $7.8 \pm 2.88$ \\
Isolate B $10^{4}$ conidia/ml & $82 \pm 10.93$ & $12.8 \pm 6$ & $5 \pm 1.66$ \\
Isolate D $10^{4}$ conidia/ml & $66.5 \pm 9.28$ & $21 \pm 6$ & $12 \pm 6.66$ \\
Isolate C $10^{4}$ conidia/ml & $82 \pm 7.26$ & $8.8 \pm 2.88$ & $8.9 \pm 2.88$ \\
\hline
\end{tabular}

Table 4. Means of coloration rates of dead P. operculella eggs after treatment with different isolates of the fungus B. bassiana with different concentrations at $28 \pm 2^{\circ} \mathrm{C}$ and relative humidity $40 \pm 5 \%$.

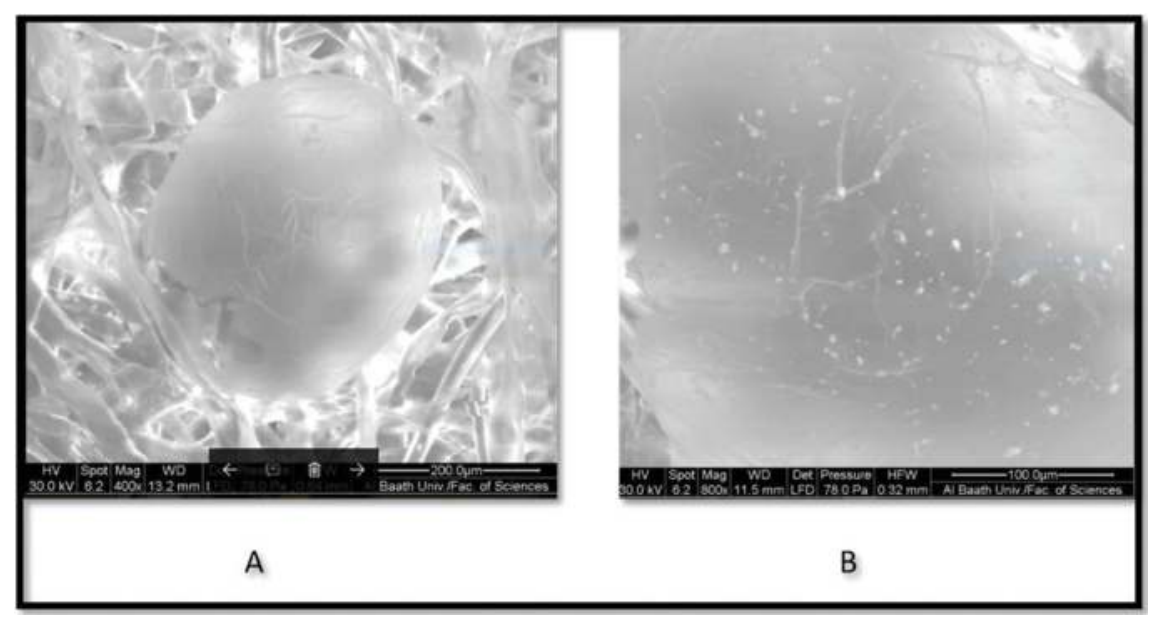

Image 1. Egg of P. operculella under SEM (A) noninfected under 400× (B) infected egg with B. bassiana under 800×.

\section{Discussion}

The results of this research showed the pathogenicity of the three native isolates of B. bassiana on egg stage of potato tuber moth, where they arrived at good death rates on eggs in different percentages between studied isolates. All results indicate to the ability of those isolates to infect the eggs stage of potato tuber moth, in spite of unsuitable condition of experiment especially the relative humidity (R.H.) was $40 \%$, which was not optimum. That effected the germination of spores. In addition, the expression of virulence for those isolates affected negatively. 
It is known that B. bassiana grows and germinates typically under $25-30^{\circ} \mathrm{C}$ and R.H. $100 \%$ [17]. Resulted death percentages from treatments with native isolates seem lower than results in similar study for the same fungus on the same moth, where egg death rate reached $76 \%$ after incubation at $25 \pm 1^{\circ} \mathrm{C}$ and R.H. $80 \pm 5 \%$ at the concentration $10^{5} \mathrm{spore} / \mathrm{ml}$ of $B$. bassiana [12], while the rate did not exceed $67 \%$ in this research in the same concentration for the best isolate (B). That can be explained by the low relative humidity while this experiment.

On the other hand, the difference between the native isolates in pathogenicity on eggs, in this research may belong to the differences in vitality of spores and in germination rates. It is known that germinated spores have vitality and they can be active in control. Therefore, they penetrate the cuticle of insect $[15,18]$. The results of germination rate showed that isolate B has higher rate of germination and with significant difference with $\mathrm{D}$ and $\mathrm{C}$. However, it has the bigger chance to penetrate the host egg because the grand number of germinated spores on egg's surface. This issue may be the main reason for egg's infection was the greatest in B isolate in comparison with $\mathrm{C}$ and $\mathrm{D}$ isolates, that must has been a near percentage of infection depending on germination percentage.

In this study, the death of moth eggs may be to stop gas exchange between the egg and arounded air, where infected eggs by B. bassiana die and some of them became black because of fungal hyphae growth in the micropyles of egg shell [19]. Previous studies showed that eggs in most insects have sculptures that differ from one insect to another, where there is micropyle on front of egg pole which represents an entrance to sperm for fecundation operation. Also aeropyles aid in the exchange of oxygen and carbon dioxide and loss of some water. Woods [20] studied all those details delicately on eggs of Manduca sexta where he found that all aeropyles as well as the micropyle and egg shell in infected eggs were occupied by fungal hyphae. Therefore, gasses exchange operation decreased and the development of embryo died [20]. Therefore, infected eggs become sterile [19].

Shalaby et al. mentioned to coloration of Tuta absoluta eggs in black after its infection by B. bassiana. T. absoluta is Gelichiid [21] and black eggs resulted from infection by concentrations ranged between $10^{7}$ and $10^{10}$ conidia/ml, death rate arrived $100 \%$. Jaksch also mentioned [22] that eggs of T. absoluta showed spots in black as a result of direct infection with B. bassiana, eggs have dried clearly 4 days after incubation, white mycelium of fungus was observed on the pole of egg and a tissue of white spores have appeared on it.

Results of this research indicated that the most of nonhatching eggs had transparent color, and they represented nonfecunded eggs. Some of nonhatched eggs had yellowish color, and they represented fecunded eggs but they did not hatch for natural reasons, so they did not have a brown color as normal fecunded eggs before hatching [23-25]. The rest of dead eggs had a black color because of infection with B. bassiana, and it forms a percentage range from 0 to $20 \%$ of dead eggs. Low percentage of black eggs may belong to the low relative humidity and low concentrations in this research in comparison with another research on eggs of Tuta absoluta. Gottwald and Tedders [26] mentioned that decrease in fungus sporulation on dead host does not necessarily correlate to mortality that can be explained by several reasons like low temperature and relative humidity in its incubation climate or lose an essential substance for the development of fungus. For the same fungus, decrease in fungus sporulation on their dead hosts can be explained by 
diversity of the virulence between strains. That attributed to their genetic diversity that supports strains in its specialization in certain host and in its geographical distribution. [27].

Eggshell's structure has an important role in spore ability to adhere on the egg surface and increases the chance to infection impact. Therefore, egg's sensibility differs between species, for example, eggs of Lepidoptera have a huge chance of death as a result of fungal infection which belongs to sculptures on eggshell $[20,28]$. Ceratitis capitata eggs are considered insensitive because they have smooth shell, where adhesion of spores is so difficult and the probability of their infection with entomopathogenic fungi seems relatively weak [29].

The importance of controlling eggs stage belongs to one hand, egg stage is fixed stage and easier in controlling than larvae in family Gelechiidae. On the other hand, Gelechiidae larvae (Ex: P. operculella, T. absoluta and Scrobipalpa ocellatella) dig tunnels inside leaves, tubers or roots, so they are protected from entomopathogenic effect. All previous makes its control so complex. Therefore, controlling eggs existing on leaves, fruits, stems and tubers represent a solution, where eggs are more exposed to natural enemies that prevent the appearance of damaging larvae from the beginning [22].

\section{Conclusion}

The pathogenicity of three local isolates of the entomopathogenic fungus Beauveria bassiana (Bals.) Vuill was evaluated on eggs of potato tuber moth $P$. operculella (Zeller). Isolates were taken from Latakia (isolate B), ICARDA spt273 (isolate C) and Damascus (isolate D). Three concentrations $10^{4}, 10^{5}$, and $10^{6}$ conidia/ml were used for each isolate; by spraying spore suspension on eggs. Eggs in the control were sprayed by sterilized water. The germination rate was evaluated after $24 \mathrm{~h}$ incubation in the dark. All tests were done under laboratory conditions of temperature $28 \pm 2{ }^{\circ} \mathrm{C}$ and relative humidity $40 \pm 5 \%$. Results showed significant differences in germination rate, where the average of germination rate was 67,55 , and $47 \%$ for isolates $B, D$ and $C$ respectively. Susceptibility tests showed significant differences in averages of hatching rate between the control and both isolates B and C when $1 \times 10^{6}$ conidia/ml was applied, with averages 18.3 and $26.6 \%$ for previous isolates respectively, in contrast $38.3 \%$ for isolate $\mathrm{D}$ and $66.6 \%$ for control. Findings indicated that eggs of $P$. operculella seemed sensible to local isolates of B. bassiana in varying degree. Results encourage further studies about the efficiency of effective isolates for controlling eggs of this pest in natural conditions of store and field and testing the local isolates on the other stages (adults and larvae) under better condition than this research condition.

\section{Author details}

Nisreen Houssain Alsaoud ${ }^{1 *}$, Doummar Hashim Nammour ${ }^{1}$ and Ali Yaseen $\mathrm{Ali}^{2}$

*Address all correspondence to: nisreensoud@gmail.com

1 Agriculture Faculty, Plant Protection Department, Albaath University, Homs, Syria

2 General Commission of Scientific Agricultural Research, Scientific Agricultural Research

Center in Tarsus, Tarsus, Syria 


\section{References}

[1] Ahmed AAI, Hashem MY, Mohamed SM, Khalil SHS. Protection of potato crop against Phthorimaea operculella (Zeller) infestation using frass extract of two noctuid insect pests under laboratory and storage simulation conditions. Archives of Phytopathology and Plant Protection. 2013;46(20):2409-2419. Available from: http://www.tandfonline.com/doi/ abs/10.1080/03235408.2013

[2] Rondon SI. The potato tuber worm: A literature review of its biology, ecology, and control. American Journal of Potato Research. 2010;87(2):149-166

[3] Sporleder M, Zegarra O, Cauti EMR, Kroschel J. Effects of temperature on the activity and kinetics of the granulovirus infecting the potato tuber moth Phthorimaea operculella Zeller (Lepidoptera: Gelechiidae). Journal of Biological Control. 2008;44(3):286-295

[4] Visser D. Guide to Potato Pests and their Natural Enemies in South Africa. Pretoria: ArcRoodeplaat Vegetable and Ornamental Plant Institute; 2005

[5] Dillard HR, Wicks TJ, Philp B. A grower survey of diseases, invertebrate pests, and pesticide use on potatoes grown in South Australia. Australian Journal of Experimental Agriculture. 1993;33(5):653-661

[6] Kroschel J. Management of the potato tuber moth Phthorimaea operculella Zeller (Lepi doptera, Gelechiidae)-An invasive pest of glob proportional. In: Proceedings of the Sixth World Potato Congress; August 20-26, 2006

[7] Arx RV, Gebhardt F. Effects of a granulosis virus, and Bacillus thuringiensis on life-table parameters of the potato tuber moth, Phthorimaea operculella. Journal of Entomophaga. 1990;35(1):151-159

[8] Cooper SG, Douches DS, Coombs JJ, Grafius EJ. Evaluation of natural and engineered resistance mechanisms in potato against Colorado potato beetle in a no-choice field study. Journal of Economic Entomology. 2007;100(2):573-579

[9] Coll M, Gavish S, Dori I. Population biology of the potato tuber moth, Phthorimaea operculella (Lepidoptera: Gelechiidae), in two potato cropping systems in Israel. Bulletin of Entomological Research. 2000;90(4):309-315

[10] Kakhki MH, Karimi J, Hosseini M. Efficacy of entomopathogenic nematodes against potato tuber moth, Phthorimaea operculella (Lepidoptera: Gelechiidae) under laboratory conditions. Biocontrol Science and Technology. 2013;23(2):146-159

[11] Carpio C, Dangles O, Dupas S, Léry X, López-Ferber M, Orbe K, Páez D, Rebaudo F, Santillán A, Yangari B, Zeddam JL. Development of a viral biopesticide for the control of the Guatemala potato tuber moth Tecia solanivora. Journal of Invertebrate Pathology. 2013;112(2):184-191

[12] Salih HAAM, Mahdi FA. The use of fungus Beauveria bassiana (Bulsamo) on tuber moth Phthorimaea operculpella (Zell.) in the Laboratory. Anbar Journal of Agricultural Sciences. 2010;4(8):334-341 
[13] Hafez M, Zaki FN, Moursy A, Sabbour M. Biological effects of the entomopathogenic fungus, Beauveria bassiana on the potato tuber moth Phthorimaea operculella (Seller). Anzeiger für Schädlingskunde Pflanzenschutz Umweltschutz. 1997;70(8):158-159

[14] Maharjan R. Rearing methods of potato tuber moth, Phthorimaea operculella (Zeller) (Lepidoptera: Gelechiidae). Academia. 2011. http://www.academia.edu/2141878/Rearing Methods_of_Potato_Tuber_Moth_Phthorimaea_operculella_Zeller_Lepidoptera_ Gelechiidae

[15] Pekrul S, Grula EA. Mode of infection of the corn earworm (Heliothis zea) by Beauveria bassiana as revealed by scanning electron microscopy. Journal of Invertebrate Pathology. 1979;247(3):238-247

[16] Abbott WS. A method of computing the effectiveness of an insecticide. Journal of Economic Entomology. 1925;18(2):265-267

[17] Walstad JD, Anderson RF, Stambaugh WJ. Effects of environmental conditions on two species of muscardine fungi (Beauveria bassiana and Metarrhizium anisopliae). Journal of Invertebrate Pathology. 1970;16(2):221-226

[18] Boucias DG, Latgé JP. Nonspecific induction of germination of Conidiobolus obscurus and Nomuraea rileyi with host and non-host cuticle extracts. Journal of Invertebrate Pathology. 1988;51(2):168-171

[19] Barsagade DD, Pankule SD, Tembhare DB. Impact of fungus on egg shell of tropical tasar silk zorm, Antheraea mylitta: An ultra-structural approach. International Journal of Industrial Entomology. 2009;18(2):77-82

[20] Woods HA, Bonnecaze RT, Zrubek B. Oxygen and water flux across eggshells of Mandoca sexta. Journal of Experimental Biology. 2004;208:1297-1308

[21] Shalaby HH, Faragalla FH, El-Saadany HM, Ibrahim AA. Efficacy of three entomopathogenic agents for control the tomato borer, Tuta absoluta (Meyrick) (Lepidoptera: Gelechiidae). Journal of Nature and Science. 2013;11(7):63-27

[22] Jaksch. Selection of isolates of Entomopathogenic fungi for control of moth eggs. Akimoo; 2012 http://www.akimoo.com/selection-of-isolates-of-entomopathogenic-fungifor-control-of-moth-eggs/

[23] Alvarez JM, Dotseth EJ, Nolte P. Potato tuber worm: A threat for Idaho potatoes. Moscow: University of Idaho Extension, Idaho Agricultural Experiment Station; 2005

[24] Rivera MJ. The potato tuber worm, Phthorimaea operculella (Zeller), in the tobacco, nicotiana. 2011

[25] Vaneva-Gancheva T. Morphological investigation on potato moth phthorimaea operculella zeller, lepidoptera, gelechiidae. Journal of Tabacco. 2009;59(3-4):81-87

[26] Gottwald TR, Tedders WL. Colonization, transmission, and longevity of Beauveria bassiana and Metarhizium anisopliae (Deuteromycotina: Hypomycetes) on pecan weevil larvae (Coleoptera: Curculionidae) in the soil. Environmental Entomology. 1984;13(2):557-560 
[27] Coates BS, Hellmich RL, Lewis LC. Allelic variation of a Beauveria bassiana (Ascomycota: Hypocreales) minisatellite is independent of host range and geographic origin-Ge nome. Génome. 2002;45(1):125-132

[28] Arbogast RT, Leonard Lecato G, Van Byrd R. External morphology of some eggs of stored-product moths (Lepidoptera pyralidae, gelechiidae, tineidae). International Journal of Insect Morphology and Embryology. 1980;9(3):165-177

[29] Ali YA. Untersuchungen zur Effektivität entomopathogener Pilze im integrierten Pflan zenschutz am Beispiel der Fruchtfliegen Ceratitis capitata und Rhagoletis cerasi (Diptera, Tephriridae). 2010 
